\title{
MAKNA TANDA PADA POSTER CANDI BOROBUDUR ASIAN GAMES 2018
}

\author{
Chrisentia Flavia Dwianjani ${ }^{1} \&$ Sella Lovityo Aulia ${ }^{2}$
}

The London School Of Public Relations Communication \& Business Institute Sudirman Park Campus, Jl. Jend. Sudirman No.Kav. 32, RT.12/RW.11, Karet Tengsin, Kota Jakarta Pusat, Daerah Khusus Ibukota Jakarta 10250

\section{Email: flaviadwianjani@gmail.com¹; Sella_lovityo@yahoo.co.id ${ }^{2}$}

\begin{abstract}
Abstrak
Kemunculan akun @asiangames2018 ini, tidak hanya menjadi sarana informasi seputar perolehan mendali, tetapi juga sebagai ajang untuk memperkenalkan pariwisata yang dimiliki oleh Indonesia dimana memiliki kekayaan budaya yang tersebar luas di seluruh wilayah ini. Secara tidak langsung juga, INASGOC juga meluncurkan enam poster yang di publish lewat official instagram dengan nama akun @asiangames2018 dimana pada poster tersebut, terlihat background yang menampilkan lokasi-lokasi destinasi wisata di Indonesia. Penelitian ini bertujuan untuk mengungkapkan tanda-tanda yang ingin disampaikan melalui poster Candi Borobudur Asian Games 2018. Penelitian ini menggunakan metode kualitatif deskriptif dengan pendekatan semiotika Roland Barthes. Simpulan dari penelitian ini adalah dapat mampu membangun semangat olahraga kedalam budaya Asia sehingga dapat semakin memperkenalkan wisata Indonesia kepada masyarakat Asia sehingga mau mengunjungi Indonesia sebagai salah satu destinasi wisata.
\end{abstract}

Kata Kunci: Roland Barthes, Semiotika, Poster, Indonesia Asian Games

\begin{abstract}
The emergence of the @ asiangames2018 account, is not only a means of information about the acquisition of medals, but also as a venue to introduce tourism that is owned by Indonesia which has a rich cultural heritage that is widespread throughout the region. Indirectly also, INASGOC also launched six posters that were published via official Instagram with the account name @ asiangames2018 where on the poster, a background was seen showing the locations of tourist destinations in Indonesia. This study aims to reveal the signs to be conveyed through the 2018 Borobudur Temple Asian Games poster. This study uses a descriptive qualitative method with Roland Barthes's semiotic approach. The conclusion of this research is able to build the spirit of sport into Asian culture so that it can increasingly introduce Indonesian tourism to Asian people so that they want to visit Indonesia as one of the tourist destinations.
\end{abstract}

Key Words: Roland Barthes, Semiotic, Poster, Indonesian Asean Game

\section{PENDAHULUAN}

Pada tahun 2018, Indonesia kembali diberi kesempatan menjadi tuan rumah Asian Games yang dimana sebelumnya Vietnam mengundurkan diri sebagai tuan rumah sehingga terpilihlah Indonesia sebagai Negara ke-18 untuk terselenggarakannya Asian Games 2018. 
Berbagai persiapan pun telah dimulai, dari awal pembukaan yang membuat banyak orang terkesima hingga menjadi trending topic yang memunculkan kekaguman akan pembukaan perlehatan olahraga, tersedianya fasilitas penginapan untuk para atlet dari 45 negara dengan jumlah 11.478 atlet yang berkompetisi di 40 cabang olahraga, fasilitas transportasi hingga penutupan yang disiapkan dengan waktu yang singkat.

Pada pembukaan Asian Games 2018, terlihat betapa antusiasnya masyarakat Indonesia dalam menyambut atlet-atlet yang akan bertanding. Walaupun dengan harga tiket yang ditawarkan oleh pihak penyelenggara pun bisa terbilang cukup mahal, tetapi tidak membuat antusias warga Indonesia tetap untuk membeli dan menonton acara pembukaan tersebut.

Sebelum pembukaan Asian Games pada tanggal 18 Agustus 2018, INASGOC (Asian Games Organizing Commite) sudah terlebih dahulu meluncurkan logo Asian Games beserta dengan meluncurkan tiga maskot yang mencuri perhatian masyarakat Indonesia.

Tidak hanya pada peluncuran logo official serta maskot saja, tetapi yang menarik perhatian juga adalah tagline dari Asian Games sendiri yaitu \#EnergyOfAsia (dalam Bahasa Indonesia adalah Energi Asia) yang semakin menambah warna dan semangat para atlet untuk bertanding.

Secara tidak langsung juga, INASGOC juga meluncurkan enam poster yang di publish lewat official instagram dengan nama akun @asiangames2018 dimana pada poster tersebut, terlihat background yang menampilkan lokasi-lokasi destinasi wisata di Indonesia.

Latar belakang yang menampilkan tempat destinasi wisata Indonesia, serta didukung dengan seorang model yang mengenakan beragam ciri khas pakaian seasia yang dipadu padankan dengan semangat Energi Asia, semakin menambah warna dalam menyambut Asian Games 2018.

Di era sekarang ini, poster pun tidak hanya ditampilkan secara cetak yang dapat dengan mudah dilihat pada papan dinding mading, tetapi karena perkembangan jaman dan teknologi yang semakin maju sehingga dengan mudah menjumpai poster pada internet. Salah satunya yang sering kita lihat di media sosial adalah instagram.

Di indonesia sendiri, hal ini mudah dijumpai bagi orang-orang yang ingin mengenal pariwisata Indonesia. Apalagi di dukung dengan berbagai informasi seputar kekayaan alam serta keindahan alam yang dimiliki oleh Indonesia yang mampu memberikan informasi secara baik dan sudah cukup untuk memenuhi kebutuhan informasi seputar pariwisata tersebut.

Kemunculan akun @asiangames2018 ini, tidak hanya menjadi sarana informasi seputar perolehan mendali, tetapi juga sebagai ajang untuk memperkenalkan pariwisata yang dimiliki oleh Indonesia dimana memiliki kekayaan budaya yang tersebar luas di seluruh wilayah ini.

Untuk itu, peneliti mengambil gambar poster yang menampilkan background Candi Borobudur karena terdorong untuk memahami dan mengkonstruksikan tanda dalam poster yang menjadi pembeda atau justru mengaitkan dan menghubungkannya dengan perlehatan Asian Games 2018 dengan citra yang ingin dibangun pemerintah Indonesia. 
Bagaimana makna tanda yang tersembunyi dari poster Candi Borobudur Asian Games, baik dalam segi warna, layout poster, pemilihan jenis font, pemilihan warna font serta konsep yang ingin digambarkan pada poster tersebut.

Sehingga bila diteliti secara jauh, maka poster mempunyai peran yang besar untuk membangun citra dalam memperkenalkan destinasi wisata Indonesia, baik itu memberikan informasi sejarah ataupun menjadikan media masa sebagai tempat promosi untuk mendatangkan wisatawan.

Berdasarkan latar belakang yang telah diuraikan oleh peneliti diatas, maka dapat dirumuskan sebuah masalah yang terdapat dalam penelitian ini yakni "Bagaimanakah makna tanda yang terkandung di dalam poster Candi Borobudur Asian Games tersebut". Merujuk pada perumusan masalah maka tujuan yang akan dicapai dalam penelitian ini adalah untuk mengungkapkan tanda-tanda yang ingin disampaikan melalui poster.

Berdasarkan penjelasan diatas, untuk melakukan penelitian terhadap makna tanda yang terdapat dalam poster Asian Games 2018, peneliti menggunakan pendekatan semiotika Roland Barthes untuk menganalisis dan mencari makna berupa dari pengunaan denotasi, konotasi dan mitos.

\section{KERANGKA TEORI}

Teori Semiotika. Semiotika telah muncul di negara-negara Anglo-Saxon. Seseorang menyebut semiologi jika ia berpikir tentang tradisi Saussurean. Dalam penerbitan-penerbitan Prancis, istilah-istilah semiologi kerap dipakai. Elements de Semiologie, misalnya, adalah salah satu judul yang dipakai oleh Roland Barthes (1964). Namun, istilah semiotics digunakan dalam kaitannya dengan karya Charles Sanders Peirce dan Charles Morris.

Sehingga sesungguhnya kedua istilah baik itu semiotika dan semiologi, sama-sama memiliki pengertian yang sama persis, walaupun penggunaan salah satu dari kedua istilah tersebut biasanya menunjukkan pemikiran pemakaiannya: mereka bergabung dengan Pierce menggunakan kata semiotika, dan mereka menggabungkan dengan Saussure menggunakan kata semiologi.

Baik semiotika maupun semiologi, keduanya kurang lebih dapat saling menggantikan karena sama-sama digunakan untuk mengacu kepada ilmu tentang tanda. Para ahli umumnya cenderung tidak begitu mau dipusingkan oleh kedua istilah tersebut, karena menganggap keduanya sebenernya sama saja.

Menurut Hawkes (dalam Sobur, 2016) bahwa istilah semiologi biasanya digunakan di Eropa, sementara semiotika cenderung dipakai oleh mereka yang berbahasa inggris. Dengan kata lain, penggunaan kata semiologi menunjukkan pengaruh kubu Saussure, sedangkan semiotika lebih tertuju kepada kubu Pierce.

Perbedaan istilah itu, menurut Masinambow (dalam buku sobur, 2016) Menunjukkan perbedaan orientasi: yang pertama (semiologi) mengacu pada tradisi Eropa yang bermula pada Ferdinand de Saussure, sedangkan yang kedua (semiotika) pada tradisi Amerika yang bermula pada Charles Sanders Pierce.

Menurut Saussure, semiologi merupakan "sebuah ilmu yang mengkaji kehidupan tanda-tanda ditengah masyarakat" dan, dengan demikian, menjadi bagian dari disiplin psikologi sosial. Tujuannya adalah untuk menunjukkan 
bagaimana terbentuknya tanda-tanda beserta kaidah-kaidah yang mengaturnya. Para ahli semiotika Prancis tetap mempertahankan istilah semiologi yang Saussurean ini bagi bidang-bidang kajiannya (Sobur, 2016, p.12).

Dengan cara itu mereka ingin menegaskan perbedaan antara karya-karya mereka dengan karya-karya semiotika yang kini menonjol di Eropa Timur, Italia, dan Amerika Serikat. Sementara, istilah semiotika atau semiotik, yang dimuncullkan pada akhir abad ke-19 oleh filsuf aliran pragmatik Amerika, Charles Sanders Pierce, merujuk kepada "doktrin formal tentang tanda-tanda" (Sobur, 2016, p.13).

Dasar dari semiotika adalah konsep tentang tanda: tak hanya bahasa dan sistem komunikasi yang tersusun oleh tanda-tanda, melainkan dunia itu sendiri pun sejauh terkait dengan pikiran manusia seluruhnya terdiri atas tanda-tanda karena, jika tidak begitu, manusia tidak akan bisa menjalin hubungannya dengan realitas (Sobur, 2016).

Bahasa itu sendiri merupakan sistem tanda yang paling fundamental bagi manusia, sedangkan tanda-tanda nonverbal seperti gerak-gerik, bentuk-bentuk pakaian, serta beraneka praktik sosial konvensional lainnya, dapat dipandang sebagai sejenis bahasa yang tersusun dari tanda-tanda bermakna yang dikomunikasikan berdasarkan relasi-relasi (Sobur, 2016).

Kata "semiotika" sendiri berasal dari bahasa Yunani, semeion yang berarti "tanda" (Sudjiman dan van Zoest, 1996) atau seme, yang berarti "penafsiran tanda" (Cobley dan Jansz, 1999). Semiotika berakar dari studi klasik dan skolastik atas seni logika, retorika, dan poetika (Sobur, 2016, p.17).

Poster adalah media komunikasi yang efektif untuk menyampaikan pesan singkat, padat dan impresif, karena ukurannya relatif besar (Kustandi dan Sujipto, 2011). Tetapi pada umumnya, poster digunakan untuk menarik perhatian orangorang yang dimana dapat memberikan informasi lebih banyak baik itu ide atau pun fakta.

Di era sekarang ini, poster pun tidak hanya ditampilkan secara cetak yang dapat dengan mudah dilihat pada papan dinding mading, tetapi karena perkembangan jaman dan teknologi yang semakin maju sehingga dengan mudah menjumpai poster pada internet. Salah satunya yang sering kita lihat di media sosial adalah instagram.

Dalam penelitian "Makna Tanda pada Poster Candi Borobudur Asian Games 2018" peneliti menggunakan semiotika Roland Barthes, dimana peneliti menganalisa tanda-tanda serta petanda yang ada dalam poster tersebut. Denotasi (makna sebenernya) yang diungkapkan oleh penulis dalam penelitian ini adalah gaya tubuh model dalam poster yang merepresentasikan makna baru (Konotasi) dalam penelitian. Dimana masing-masing tanda memiliki makna lain yang ingin dibandung dalam kehidupan sehari-hari.

Komunikasi Non-Verbal. Komunikasi nonverbal sebagai setiap perilaku dan karakteristik yang mengirimkan makna tanpa menggunakan kata-kata. Dalam hidup nyata komunikasi nonverbal ternyata jauh lebih banyak dipakai daripada komunikasi verbal, dengan kata-kata. Dalam berkomunikasi hampir secara otomatis komunikasi nonverbal ikut terpakai. Karena itu, komunikasi nonverbal bersifat tetap dan selalu ada (Floyd, 2009). 
Komunikasi nonverbal lebih jujur mengungkapkan hal yang mau diungkapkan karena spontan. Tamu di rumah kita, meski lapar, dapat berbasa-basi menolak pada waktu kita tawari makan siang. Tetapi adik kecil yang masih bayi, pada waktu lapar langsung menangis dan minta ASI (Floyd, 2009).

Meskipun lebih umum, terus-menerus dipakai dan lebih jujur, namun komunikasi nonverbal lebih sulit ditafsir karena kabur. Misalnya, jika ada orang tersenyum kepada kita, maka kita tidak dapat dengan cepat menangkap apa artinya: senang, kaget, bingung atau bertanya-tanya. Kekaburan ini disebabkan karena struktur komunikasi nonverbal tidak jelas (Floyd, 2009).

Susunan suatu komunikasi nonverbal, misalnya berjabat tangan, mungkin masih mudah dimengerti. Tetapi jika jabat tangan itu disambung dengan raut wajah seperti cemberut, gerak mata seperti terkejut, gerak anggota tubuh seperti kaku dan seluruh tubuh yang tegang, kita sulit mengartikannya (Floyd, 2009).

Makna. Makna adalah bagian yang tidak terpisahkan dari semantik dan selalu melekat dari apa saja yang kita tuturkan. Pengertiannya sendiri sangatlah beragam. Menurut Mansoer Pateda (2001) mengemukakan bahwa istilah makna merupakan kata-kata istilah yang membingungkan. Makna tersebut selalu menyatu pada tuturan kata maupun kalimat. Tetapi berbeda pendapat menurut Ullman (dalam Pateda, 2001) bahwa makna adalah hubungan antara makna dengan pengertian.

Jika ditarik kesimpulan mengenai arti makna adalah suatu kebahasaan yang harus dianalisis dalam batas unsur-unsur penting situasi dimana penutur mengujarnya yang merupakan hubungan antara bahasa dengan bahasa luar yang disepakati bersama oleh pemakai bahasa sehingga dapat saling dimengerti. Batasan tentang pengertian makna sangat sulit ditentukan karena setiap peakai bahasa memiliki kemampuan dan cara pandang yang berbeda dalam memaknai sebuah ujaran atau kata.

\section{METODE PENELITIAN}

Jenis penelitian ini menggunakan pendekatan kualitatif deskriptif dengan pendekatan semiotika Roland Barthes. Menurut Creswell (2010), penelitian kualitatif adalah metode-metode untuk mengeksplorasi dan memahami makna yang oleh sejumlah individu atau sekelompok orang yang dianggap berasal dari masalah sosial atau kemanusiaan.

Unit Analisis. Unit analisis pada penelitian ini berupa "Poster Candi Borobudur Asian Games 2018", yang telah dipublikasikan sejak 12 Juli 2018. Sedangkan objek yang akan di analisa adalah berupa gambar yang ada dalam poster, sehingga nantinya peneliti dapat menganalisis makna dari tanda yang terkandung dalam Poster Candi Borobudur Asian Games 2018 yang berdasarkan pengamatan peneliti dengan menggunakan analisis semiotika Roland Barthes.

Adapun focus penelitian ini adalah sebagai berikut:

Tabel 1. Fokus Penelitian

Objek Elemen Efidensi




\begin{tabular}{lll}
\hline Makna Tanda Pada Poster & Denotasi & Tipografi \\
Candi Borobudur Asian & Konotasi & Layout Poster \\
Games 2018 & Mitos & Logo Asian Games \\
& Warna \\
& Teknik Pengambilan \\
& Gambar \\
& Penampilan Fisik dan \\
& Bahasa Tubuh \\
& Ekpresi Wajah \\
& Bentuk Bibir yang Datar \\
& Bentuk Alis yang Terlihat \\
& Naik \\
& Hiasan Kepala \\
& Pakaian yang Digunakan \\
& Cara Memegang Panah
\end{tabular}

Sumber : Data Olahan Peneliti, 2018

Metode yang digunakan ialah bersumber pada data sekunder (Neuman, 2017) yang bersumber pada:

1. Studi Literatur. Peneliti mencari sumber literasi yang memiliki pengetahuan pengalaman yang konstektual. Penelitian ini secara sistematis guna memudahkan penelitian untuk mengetahui yang digunakan dalam penelitian poster ini. Di dapat dengan cara melihat poster Candi Borobudur Asian Games 2018 di social media seperti instagram maupun internet guna memperlancar penelitian serta untuk memudahkan mengamati poster tersebut dengan cermat yang mana sesuai dengan data yang diperoleh.

2. Riset Perpustakaan. Dalam penelitian ini, peneliti mempelajari dan menggunakan referensi dari buku-buku ilmiah, jurnal dan skripsi terdahulu, serta berbagai karya ilmiah yang berkaitan dengan penelitian.

Metode analisis semiotika Roland Barthes. Seperti yang telah dijelaskan sebelumnya. Dalam analisis semiotika menurut barthes, dasar dari semiotika adalah konsep tentang tanda dimana tidak hanya bahasa dan sistem komunikasi yang tersusun oleh tanda-tanda.

Adapun teknik analisis data yang digunakan dalam penelitian ini adalah metode analisis semiotika Roland Barthes. Seperti yang telah dijelaskan sebelumnya. Dalam analisis semiotika menurut barthes, dasar dari semiotika adalah konsep tentang tanda dimana tidak hanya bahasa dan sistem komunikasi yang tersusun oleh tanda-tanda.

Adapun makna yang diklasifikasikan kedalam tiga komponen yang berupa Konotasi, Denotasi, dan Mitos (Barthes, 2011).

1. Konotasi. Konotasi adalah order of signification yang kedua yang berisi perubahan makna kata secara asosiatif. Menurut Barthes, hal ini hanya berlaku pada tataran teoritis. Pada tataran praktis, membatasi makna ke dalam sebuah denotative akan sangat sulit karena tanda selalu meninggalkan jejak makna dari konteks sebelumnya.

2. Denotasi. Denotasi adalah order of signification yang pertama. Pada tingkatan ini terdapat sebuah tanda yang terdiri atas sebuah signifier dan sebuah signified. Dalam arti, denotation merupakan apa yang di pikirkan sebagai sebuah 
literal, bersifat tetap dan memiliki makna kamus sebuah kata yang secara ideal telah disepakati secara universal.

3. Mitos. Menurut Barthes, mitos adalah signification dalam tingkatan connotation. Jika sebuah tanda diadopsi secara berulang dalam dimensi syntagmatic maka bagian adopsi akan terlihat lebih sesuai dibandingkan dengan penerapan lainnya dalam paradigmatic. Kemudian connotation tanda menjadi dinaturalisasi dan dinormalisasi. Naturalisasi mitos adalah sebuah bentukan budaya.

\section{PEMBAHASAN}

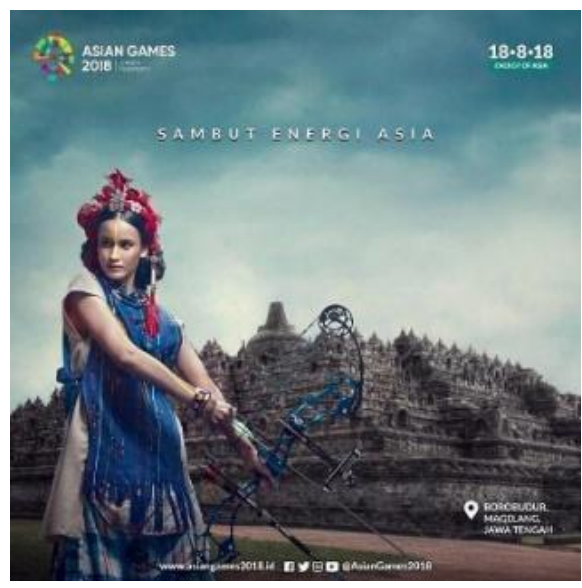

Gambar 1. Poster Candi Borobudur Asian Games 2018

Poster Candi Borobudur Asian Games 2018 tersebut adalah salah satu bentuk kampanye untuk menyambut para atlet serta turis dari seluruh Asia dimana merepresentasikan Asia dengan paduan latar belakang lokasi Indonesia. Pada foto tersebut, terlihat seseorang sedang berdiri sambil memegang sebuah panah dan menoleh ke samping. Terlihat pula latar belakang yang diambil menampilkan Candi Borobudur.

Untuk itu, dalam menganalisis sebuah poster kita terlebih dahulu membahas mengenai tanda-tanda yang ada di dalam poster Candi Borobudur Asian Games 2018 dapat diuraikan sebagai berikut:

\begin{tabular}{|c|c|}
\hline Evidensi & Tanda \\
\hline Naskah Poster & $\begin{array}{l}\text { "Sambut Energi Asia" dan "Borobudur, Magelang, Jawa } \\
\text { Tengah". }\end{array}$ \\
\hline Tipografi & $\begin{array}{l}\text { Jenis tulisan tipis dan tergolong tulisan Lato (jenis huruf } \\
\text { yang tidak memiliki kait di bagian ujung garis). }\end{array}$ \\
\hline Layout Poster & $\begin{array}{l}\text { Pada poster tersebut dibagian tengah terdapat tulisan } \\
\text { "Sambut Energi Asia" berwarna putih dan di pojok kanan } \\
\text { dan kiri atas terdapat logo Asian Games } 2018 \text { serta tanggal } \\
\text { pembukaan Asian Games 2018. Di bawah pojok kanan } \\
\text { terdapat tulisan "Borobudur, Magelang, Jawa Tengah" serta } \\
\text { pada bagian bawah tengah poster disertai website beserta }\end{array}$ \\
\hline
\end{tabular}


dengan akun social media Asian Games 2018.

\begin{tabular}{|c|c|}
\hline $\begin{array}{l}\text { Logo Asian Games } \\
2018 \text { pada pojok kiri } \\
\text { atas }\end{array}$ & $\begin{array}{l}\text { Logo yang tertera di dalam poster tersebut adalah logo } \\
\text { Asian Games } 2018 \text { yang di tengah logo terdapat simbol } \\
\text { sinar matahari. Logo tersebut terdiri dari warna merah, } \\
\text { biru laut, hijau gelap, orange, kuning, tosca, pink, ungu, hijau } \\
\text { serta biru gelap dan berbentuk dari bentuk stadium Gelora } \\
\text { Bung Karno. }\end{array}$ \\
\hline Warna & $\begin{array}{l}\text { Warna yang ada pada poster tersebut didominasi oleh biru, } \\
\text { merah, hitam serta cokelat muda. }\end{array}$ \\
\hline $\begin{array}{l}\text { Teknik Pengambilan } \\
\text { Gambar }\end{array}$ & $\begin{array}{l}\text { Jika dilihat dari penempatan objeknya, foto yang ada pada } \\
\text { poster tersebut termasuk foto yang menggunakan teknik } \\
\text { Medium Long Shot serta pada latar belakang tempatnya } \\
\text { menggunakan teknik Extreme Long Shot. }\end{array}$ \\
\hline $\begin{array}{l}\text { Penampilan Fisik dan } \\
\text { Bahasa Tubuh }\end{array}$ & $\begin{array}{l}\text { Orang di dalam foto tersebut menggunakan pakaian } \\
\text { tradisional berwarna biru dengan corak garis-garis, cokelat, } \\
\text { mengenakan hiasan kepala berwarna merah. Orang tersebut } \\
\text { sedang berdiri sambil memegang sebuah panah, sedangkan } \\
\text { badan, tangan serta kepalanya condong ke arah sebaliknya. }\end{array}$ \\
\hline Ekpresi wajah & $\begin{array}{l}\text { Orang yang terdapat pada poster tersebut terlihat memiliki } \\
\text { tatapan yang serius terlihat dari arah mata yang } \\
\text { memandang secara tajam. }\end{array}$ \\
\hline $\begin{array}{l}\text { Bentuk bibir yang } \\
\text { datar }\end{array}$ & $\begin{array}{l}\text { Jika dilihat dari ekpresi yang ditampilkan oleh orang } \\
\text { tersebut, terlihat keseriusan yang terlihat jelas dari bentuk } \\
\text { bibir yang datar. }\end{array}$ \\
\hline $\begin{array}{l}\text { Bentuk alis yang } \\
\text { terlihat naik }\end{array}$ & $\begin{array}{l}\text { Terlihat pada ujung alis terlihat naik yang memiliki sikap } \\
\text { serius. }\end{array}$ \\
\hline $\begin{array}{l}\text { Garis berwarna kuning } \\
\text { yang ada pada wajah } \\
\text { serta lengan }\end{array}$ & $\begin{array}{l}\text { Pada objek poster tersebut, terlihat garis kuning yang } \\
\text { berada pada lengan serta wajah yang ada pada dahi hingga } \\
\text { hidung yang memberikan aksen tambahan tradisional. }\end{array}$ \\
\hline $\begin{array}{l}\text { Hiasan kepala yang } \\
\text { digunakan }\end{array}$ & $\begin{array}{l}\text { Hiasan yang berwarna merah ini, mengambil unsur dari } \\
\text { suku pedalaman Thailand dan Borneo. }\end{array}$ \\
\hline $\begin{array}{l}\text { Pakaian } \\
\text { digunakan }\end{array}$ & $\begin{array}{l}\text { Terlihat pakaian yang digunakan memadukan budaya } \\
\text { Toraja dan tenun Makassar yang berwarna biru dan celana } \\
\text { dengan motif kotak-kotak. Di kombinasi dari budaya } \\
\text { Makassar, Bugis, Mandar dan Toraja menjadi benang merah } \\
\text { yang ditampilkan lewat pakaian yang dikenakan orang } \\
\text { tersebut di dalam poster. }\end{array}$ \\
\hline objek/orang & Jika kita melihat pada poster, orang tersebut sedang \\
\hline
\end{tabular}



pada cara memegang tersebut, menggunakan teknik dasar Hooking and Gripping The Bow.

\section{Sumber: Data Olahan Peneliti, 2019}

Makna Denotasi. Naskah poster ini terbagi menjadi dua bagian, yaitu "Sambut Energi Asia" dan "Borobudur, Magelang, Jawa Tengah". Dari kedua naskah tersebut, "Sambut Energi Asia" menjadi naskah yang menjelaskan keterkaitan foto dengan perlehatan Asian Games. Naskah ini menjadi satu-satunya sumber informasi dimana tagline Asian Games dihadirkan dalam naskah utama.

Pada tulisan "Borobudur, Magelang, Jawa Tengah" memperkuat makna poster dengan membubuhkan informasi tentang latar tempat yang terpilih menjadi salah satu tempat pariwisata populer yang ikut di promosikan pada poster tersebut.

Jenis tulisan yang digunakan dalam poster Candi Borobudur Asian Games 2018 tersebut adalah tulisan Lato. Lato adalah jenis tulisan yang masuk pada kategori Sans Serif dimana tidak memiliki kait di ujung garis (Dewabrata, 2012).

Jenis tulisan ini menjadi pilihan penyelenggara Asian Games 2018 yaitu INASGOC untuk digunakan pada seluruh materi desain ataupun media yang meliput pertandingan tersebut, sehingga penggunaan jenis tulisan Lato yang tipis seperti yang tertera pada poster tersebut, memperkuat trademark Asian Games 2018.

Penyusunan elemen desain pada poster ini cukup sederhana dan presisi, logo Asian Games 2018 di pojok kiri atas, logo "18.8.18” yang terdapat di pojok kanan atas, naskah poster "Sambut Energi Asia" ditengah atas serta naskah poster "Borobudur, Magelang, Jawa Tengah" yang terdapat di bawah kanan. Jarak antara sisi masing-masing elemennya pun sama, antara satu dengan yang lainnya. Hal ini membuat poster tersebut kelihatan rapi dan nyaman dipandang mata. Layout atau penyusunan elemen desain seperti ini cocok dengan konsep yang dihadirkan panitia INASGOC yang rapi, simple dan light.

Logo Asian Games 2018 yang digunakan pada poster tersebut adalah logo official yang dikeluarkan oleh panitia penyelenggara, yang terinspirasi dari bentuk bangunan Stadium Gelora Bung Karno dan tengahnya terdapat gambar matahari yang diambil dari logo Olympic Council of Asia. Sehingga masyarakat dapat memahami secara cepat bahwa poster tersebut adalah bagian dari media promosi Asian Games 2018.

Warna yang ada pada poster tersebut adalah warna biru, merah, hitam serta cokelat muda yang dapat terlihat dengan jelas pada objek orang yang sedang memegang sebuah panah. Warna biru, putih dan hitam dinilai mendominasi poster tersebut memiliki latar belakang yang didominasi oleh awan dan Candi Borobudur, sehingga warna-warna natural seperti biru (warna langit) dan warna hitam (warna Candi Borobudur) yang mendominasi poster tersebut (Stone, 2008).

Teknik pengambilan pada poster tersebut tergolong kedalam gambar Medium Long Shot, karena setengah bagian tubuh orang yang ada di dalam poster tersebut, masuk ke dalam frame dan tidak mendominasi seluruh bagian poster sehingga latar belakang pun masih terlihat jelas. Sedangkan pada area latar belakang tergolong Extreme Long Shot karena tampak jelas bagian-bagian dari Candi Borobudur yang ingin ditampilkan pada poster tersebut. 
Orang yang ada di dalam poster tersebut mengenakan pakaian tradisional dari berbagai negara di Asia Tenggara, hiasan kepala yang berwarna merah dan rok kotak-kotak berwarna biru. Orang tersebut terlihat sedang berdiri dengan memegang sebuah panah dengan kepala serta badannya condong kearah sebaliknya.

Expresi wajah pada poster tersebut, terlihat memiliki tatapan menghadap arah menyerong kiri atas menunjukkan fokus dengan apa yang ada didepannya. Terlihat pada bagian alis yang naik pada ujungnya dan diikuti dengan bentuk bibir yang tertutup rapat (Wibisono, 2018). Makna pada bentuk bibir datar dapat diartikan sebagai pendukung rada tidak mudah menyerah dimana di maksudkan adanya hasrat ingin mencapai sesuatu. Pada poster tersebut, dapat juga merupakan isyarat dari orang yang berusaha secara aktif melawan hal yang tidak menyenangkan, marah serta ingin menentang (Wibisono, 2018). Bentuk alis yang lurus tetapi pada ujung alis terlihat naik, dapat diartikan bahwa individu tersebut menunjukan sikap yang serius dalam melakukan sebuah hal sehingga dapat dilihat juga pada daerah dahi terlihat sedikit kerutan yang diartikan sebagai sikap optimis untuk menggapai sesuatu (Ackermen, 2012).

Hiasan kepala yang digunakan oleh poster tersebut di dominasi dengan warna merah dengan aksen pernak-pernik dari ciri khas layaknya suku pedalaman Thailand dan Borneo. Warna merah dapat diartikan sebagai semangat, energi dan keberanian, sehingga terpancar jelas pada poster tersebut. Pakaian yang digunakan pada poster tersebut adalah memadukan budaya Toraja dan tenun Makassar yang berwarna biru dan celana dengan motif kotak-kotak. Di kombinasi dari budaya Makassar, Bugis, Mandar dan Toraja menjadi benang merah yang ditampilkan lewat pakaian yang dikenakan orang tersebut di dalam poster.

Terlihat pada motif Tenun Toraja menjadi perlambangan status sosial yang dibuat dengan teknik ikat dan megah sedangkan pada Tenun Makassar bermotif unik dan warna cerah. Sehingga perpaduan motif dari Tenun Toraja dan warna cerah dari Tenun Makassar ingin menampilkan perpaduan yang dinamis antar suku.

Pada poster tersebut, terlihat pula orang memegang sebuah sebuah panah beserta dengan busur dan terlihat menggunakan teknik dasar yaitu Hooking and Gripping The Bow dimana gerakan memanah dengan menempatkan maupun mengaitkan jari di tali setelah anak panah atau nocking point terpasang dengan benar.

Pemaknaan denotasi pada Poster Candi Borobudur Asian Games 2018 adalah penggambaran wanita yang sedang memegang alat panah yang menggunakan hiasan kepala, baju adat dari berbagai budaya di Asia serta penggunaan warna cerah pada penampilannya tersebut. Wanita pada poster tersebut menunjukan sisi jiwa pantang menyerah dan berani namun tetap terlihat menawan.

Makna Konotasi. Kedua naskah yang tertera pada poster tersebut, ditulis dengan bahasa yang sederhana dan menggunakan bahasa pribumi, yaitu Bahasa Indonesia. Cara penyampaian pesan yang sederhana ini, sesuai dengan gambaran umum Asian Games 2018. Tulisan "Sambut Energi Asia" merupakan salah satu bagian tagline dari Asian Games 2018 sehingga masyarakat dapat memahami bahwa poster tersebut merupakan bagian bentuk kampanye untuk mensukseskan perlehatan olahraga tersebut.

Letak lokasi latar belakang Candi Borobudur pun semakin menguatkan bahwa latar tempat tersebut memang merupakan salah satu tempat yang terkenal 
bila mancanegara mengunjungi Indonesia. Tidak hanya pada latar belakang saja, melainkan situs yang dimuat memudahkan orang yang melihat poster tersebut dapat mengetahui updated mengenai persiapan serta perlehatan olahraga Asian Games 2018.

Melalui identitas dan situs yang dituliskan, seseorang dapat dengan mudah mencari foto melalui situs-situs yang mengupload kembali keenam poster yang ditampilkan untuk memperkenalkan pariwisata di Indonesia. Keberadaan foto asli ini dapat membuat masyarakat membuat foto dengan kualitas seperti yang ada pada poster tersebut.

Jenis tulisan Lato digunakan untuk menulis naskah pada poster tersebut adalah merupakan standar yang dibuat INASGOC untuk diterapkan diseluruh media desainnya.

Tata letak seluruh elemen poster Candi Borobudur Asian Games 2018 ini cukup sederhana. Poster tersebut terdiri atas logo yang terletak di pojok kiri atas beserta dengan tanggal pembukaan Asian Games 2018, tulisan "Sambut Energi Asia" dibagian tengah atas dan tulisan "Borobudur, Magelang, Jawa Tengah" di bagian pojok kanan bawah.

Jika dilihat secara berurutan, letak logo Asian Games 2018, letak logo tanggal pembukaan, tulisan "Sambut Energi Asia" dan tulisan "Borobudur, Magelang, Jawa Tengah" menunjukkan pesan apa yang paling penting dalam poster tersebut. Asian Games merupakan bentuk perlehatan olahraga terbesar kedua setelah olympic yang di hadiri berbagai negara Asia, sehingga elemen yang paling penting akan diletakkan di sebelah kiri.

Elemen yang berada di sebelah kiri adalah logo Asian Games 2018, sehingga masyarakat tahu bahwa poster tersebut adalah salah satu bentuk kampanye untuk membangun semangat dalam menyambut Asian Games 2018. Di sebelah logo tersebut, terdapat logo "18.8.18" yang juga menjelaskan bahwa opening ceremony Asian Games 2018 dilakukan pada tanggal 18 Agustus 2018.

Pada sisi kanan bawah, terdapat tulisan "Borobudur, Magelang, Jawa Tengah" yang menunjukkan latar tempat yang menjadi icon poster tersebut serta alamat situs resmi dan social media Asian Games 2018 terdapat di bagian bawah tengah dapat digunakan untuk membuat masyarakat melakukan pencarian tentang kampanye, perolehan medali, informasi tambahan mengenai Asian Games tersebut.

Logo Asian Games 2018 yang dipakai pada poster tersebut adalah logo yang disebut "Energy of Asia". Logo tersebut hadir dengan desain yang sederhana, dimana terinspirasi dari bentuk bagian atas Stadium Utama Gelora Bung Karno yang ditengahnya adalah matahari, diambil dari simbol Olympic Council of Asia. Logo tersebut menggambarkan energi yang kuat dalam merefleksikan dan mempromosikan Indonesia ke Dunia (Imam, 2016, Juni 28).

Warna-warni pada logo, warna putih pada tulisan merupakan pemilihan warna yang mengingatkan kita adanya perbedaan warna budaya dari berbagai Asia. Elemen yang paling mendominasi pada logo tersebut adalah merah, biru laut, hijau gelap, orange, kuning, tosca, pink, ungun, hijau serta biru gelap. Ditambah dengan warna biru pada luaran orang yang ada dalam poster. Hal ini membuat warna dominan tersebut adalah biru. Biru adalah warna ketenangan, kesunyian, kedamaian, kenyamanan dan perlindungan (Stone, 2008) 
Penggunaan warna biru pada poster tersebut memiliki kaitan visi Asian Games 2018 yang mengatakan bahwa dalam menyukseskan perlehatan Asian Games 2018 ini adalah dengan menjadi penduduk Indonesia yang ramah dan bermartabat. Pernyataan tersebut juga menunjukkan bahwa Asian Games 2018 tetap bersatu walaupun berbeda tetapi tetap satu.

Poster tersebut yang menampilkan latar belakang Candi Borobudur yang menjadi salah satu pusat wisata terkenal di Magelang, Jawa Tengah. Candi Borobudur pun menjadi pusat wisata favorite yang di dalamnya banyak menyimpan nilai sejarah.

Poster tersebut menggunakan teknik pengambilan gambar Medium Long Shot. Meskipun teknik pengambilan gambar tersebut tergantung pada seberapa banyak bagian tubuh sebuah objek foto yang dipotret, namun poster tersebut terlihat menonjolkan latar belakang foto tersebut. Orang yang ada di dalam foto berdiri di sebelah kiri sambil memegang sebuah panah dengan posisi menyamping.

Gaya orang yang ada di dalam foto pun menunjukkan detail ekpresi muka, emosi orang yang jelas serta pakaian yang digunakan terlihat jelas, sehingga orang ada di dalam foto menunjukkan bukti keberanian serta penuh dengan keberanian.

Terlihat pada pakaian yang dipakai oleh orang yang ada di dalam foto, menggunakan pakaian yang memadukan blus dari bahan linen, tenun Toraja dan tenun Makassar yang berwarna bitu dan celana dengan motif kotak-kotak. Tidak hanya itu saja, headpiece yang dikenakan orang tersebut mampu memberikan mood layaknya suku pedalaman di Thailand dan Borneo, sehingga sangat cocok digunakan untuk menampilkan beragam suku di Asia.

Warna dominan pakaian yang di gunakan oleh orang tersebut, rata-rata merupakan warna natural, seperti biru, cokelat dan merah. Warna-warna tersebut adalah warna-warna alam, sesuai dengan tempat yang di dalam potret tersebut.

Orang yang ada di dalam poster tersebut terlihat sedang berdiri dengan menghadap menyamping, sedangkan terlihat dengan jelas bagian kepala serta tangan condong kearah yang sama. Saat gambar diperbesar, terlihat bahwa orang tersebut berekspresi dengan tatapan yang serius dan tajam. Ekpresi yang ditunjukkan oleh orang tersebut seperti sedang bersiap-siap menembak sebuah sasaran. Terlebih, tangan kiri orang tersebut memegang sebuah panah dan busur. Posisi tangan kiri orang tersebut menggantung di udara, hal ini menguatkan argumen bahwa orang tersebut sedang bersiap-siap menembak panah kearah sasaran yang dituju. Gerakan orang yang ada di dalam foto seperti sikap ke waspadaan terhadap musuh yang akan datang.

Hal ini serupa dengan gambaran ide awal terbentuknya poster dengan mengenalkan warna Indonesia, yaitu untuk menyambut bangsa-bangsa Asia yang data ke perlehelatan pesta olahraga terbesar kedua di Asia dengan mengenalkan wajah-wajah Asia ke Masyarakat.

Pada konotasi dalam Poster Candi Borobudur Asian Games 2019 adalah warna-warna yang paling menonjol adalah biru menunjukkan sisi ketenangan, kedamaian. Headpiece berwarna merah mampu memberikan suasana layaknya suku pedalaman di Thailand dan Borneo. Terlebih lagi diperlihatkan wanita tersebut memegang panah yang menunjukkan sikap kewaspadaan terhadap sesuatu. 
Mitos. Naskah poster yang digunakan sejak awal peluncuran, terdiri dari jumlah kata yang sedikit yang dimana memasukkan motto yang diangkat pada perlehatan Asian Games 2018 bahkan memiliki enam seri objek wisata di Indonesia yang terdiri dari Pura Ulu Danu Beratan di Bali, Panta Gigi Hiu di Lampung, Borobudur di Magelang, Gunung Rinjani Lombok di Nusa Tenggara Barat, Tana Toraja di Sulawesi Selatan dan Pulau Padar di Nusa Tenggara Timur.

"Sambut Energi Asia", serta keterangan tentang tempat dan situs resmi tempat untuk mendapatkan informasi lebih yang ditampilkan, menghadirkan kesan pengalaman foto yang praktis namun tetap berkualitas baik. Karakter naskah poster maupun konsep mengikuti era post modern ini, cocok dengan konsep ingin menyambut kehadiran orang-orang yang akan berkunjung ke Indonesia. Konsep menawan yang ditunjukkan oleh Asian Games 2018, diperkuat dengan jenis tulisan Lato yang cenderung mudah dibaca dari jarak dekat dan lebih nyaman karena jenis tulisan yang digunakan oleh INASGOC, tidak memiliki garis yang tebal maupun terlalu kasar/tajam. Penggunaan jenis tulisan tersebut memberi kesan minimalis dan lebih berkelas. Ukuran tulisan yang tipis memperkuat kesan-kesan tersebut.

Latar belakang yang diangkat adalah Candi Borobudur yang letaknya di Magelang, Jawa Tengah yang dimana dibangun di atas bukit dengan bentuk piramida berundak dan terbuat dari batuan andesit yang berjumlah lebih dari 2,000,000 blok. Bagian atas berbentuk stupa yang beralaskan tiga teras berbentuk lingkaran merupakan gaya arsitektur India sedangkan bagian bawahnya berbentuk poligon merupakan gaya arsitektur Jawa yang menjadi satu kesatuan.

Stupa di Candi Borobudur mengadaptasi konsep Buddha yang merupakan refleksi dari alam semesta. Untuk memahami cerita yang terpahat di Candi Borobudur harus berjalan searah jarum jam yang disebut "pradaksina". Dalam ajaran agama Budha pradaksna berarti menghormati roh-roh suci yang berada di Candi. Candi Borobudur terbagi menjadi tiga bagian :

1. Bagian Pertama yaitu Kamadhatu, melambangkan kehidupan duniawi dan manusia yang bisa mengekang hawa nafsu, disimbolkan oleh pondasi.

2. Bagian kedua yaitu Rupadhatu, melambangkan kehidupan manusia yang bisa mengekang jawa nafsunya tapi masih terikat oleh bentuk dan wujud.

3. Bagian ketiga disebut Arupadhatu, melambangkan nirwana yang disimbolkan oleh tiga teras berbentuk lingkaran.

Seperti yang kita ketahui, Candi Borobudur memilik berbagai relief yang sampai sekarang masih belum terpecahkan dan hanya beberapa relief yang berhasil di artikan kisahnya yaitu ada pada bagian atas Rupadhatu yang menceritakan tentang kehidupan Buddha Gautama yang disebut dengan nama Lalitavistara.

Relief tersebut menceritakan tentang biografi Buddha Gautama dari awal kelahirannya di Lumbini Garden (Nepal). Ibu Sidharta bernama Maya Dewi akhirnya meninggal tepat satu minggu setelah melahirkan. Setelah beranjak dewasa, Sidharta menikah dengan seorang putri bernama Puteri Gopa.

Pada suatu hari Sidharta keluar dari istana dan mendapati beberapa fenomena ganjil yang belum pernah ia lihat sebelumnya: orang buta yang sakit, orang yang meninggal serta seorang pendeta. Setelah melihat fenomena-fenomena tersebut akhirnya Sidharta memutuskan meninggalkan istana dan menjadi seorang pertapa (Wanaprasta). 
Ketika menjadi seorang pertapa, Sidharta menjadi pengikut beberapa guru terkenal seperti Brahmapani, Rydraka, Arada Kapala, serta lima pertapa terkenal lainnya. Namun demikian Sidharta merasa tidak puas dengan apa yang telah diajarkan oleh para guru-gurunya. Sidharta akhirnya memutuskan untuk bertapa di bawah pohon Bodhi di kota Bodh Gaya, India. Di sanalah dia mendapatkan pencerahan dan menjadi Bodhi yang kemudian merubah namanya menjadi Buddha Gautama.

Jika dilihat dari mitos yang terkandung saat kita mengunjungi Candi Borobudur, salah satunya yang terkenal adalah Kunto Bimo. Dimana perilaku menyentuh stupa yang berada di bagian dalam stupa dianggap dapat memberikan harapan atau impian dapat terkabul. Kunto Bimo sendiri adalah patung Buddha dalam posisi "Dharmachakra" yang berada di dalam stupa dengan penutup belah ketupat dan berada pada tingkat dasar dari tiga undak-undak stupa.

Bila berniat untuk memegang sang Buddha maka disarankan bagi laki-laki memegang kelingking atau jari manis Buddha, sedangkan untuk perempuan berusaha memegang bagian jari kaki Buddha. Tetapi pada kenyataanya banyak orang yang tidak berhasil melalukan tradisi tersebut.

Dibalik kepopulerannya, mitos tersebut dapat membahayakan pengunjung terlebih lagi untuk kelestarian Candi Borobudur apalagi bila sering disentuh akhirnya lama-lama akan rusak dan dapat mempercepat pelapukan archa Buddha yang ada di dalamnya. Seperti yang telah disampaikan, mitos tersebut tidak ada kaitannya dengan ajaran Agama Buddha.

Pada gambar wanita yang sedang memegang sebuah panah yang dimana pada tradisi Jawa Kuno dikenal sebagai Jemparingan. Tradisi tersebut dahulu dimainkan oleh para bangsawan kerajaan dan juga keluarganya dan Raja Kerajaan Mataram pun menjadikan permainan ini sebuah perlombaan wajib di wilayaj kerajaan kala itu.

Para prajurit di zaman kerajaan melakukan tradisi jemparingan ini guna melatih ketajaman konsentrasi dalam melesatkan anak panah. Lambat laut, tradisi jemparingan ini menyebar ke kerajaan sebelah bahkan bangsa asing juga melakukannya. Eksistensi tradisi ini semakin menjamur kian hari mengingat panahan juga merupakan olahraga yang bukan hanya berfungsi untuk latihan fisik namun juga latihan jiwa.

Tidak seperti permainan panahan pada umumnya yang dilakukan dengan posisi berdiri, tetapi jemparingan dilakukan dengan posisi duduk bersila. Peserta biasanya duduk dengan gaya mataraman membentuk dua barisan dengan menghadap ke barat. Posisi duduk ini disebabkan karena dahulu para bangsawan biasanya memanah sambil bercengkrama membicarakan bisnis sambil menikmati kopi,teh atau makanan ringan.

Selain itu, aktivitas memanah juga mewajibkan para peserta untuk mengenakan pakaian adat tradisional Jawa lengkap dengan jarik, blangkon, kebaya untuk peserta perempuan dan beskap untuk peserta laki-laki. Bahkan ada yang melengkapinya dengan keris. Oleh karena itu, tidak jarang nuansa tradisional zaman dahulu kerap dijumpai pada aktivitas panahan jemparingan ini.

Mitos yang dimaknai dalam Poster Candi Borobudur Asian Games 2018 adalah bahwa penanda, petanda dan tanda yang terdapat dalam poster tersebut 
menjelaskan gambaran sosok wanita yang tidak mudah pantang menyerah dan selalu siap dalam menghadapi sebuah tantangan.

\section{KESIMPULAN}

Berdasarkan hasil analisis makna tanda pada poster Candi Borobudur Asian Games 2018 dengan teori semiotika Roland Barthes, berdasarkan makna denotasi, konotasi dan mitos yang terkandung dalam poster tersebut, dapat ditarik sebuah kesimpulan bahwa kebudayaan dari berbagai negara di Asia digambarkan secara jelas melalui tampilan wanita yang ada pada poster tersebut. Tidak hanya ingin menciptakan suasana perhelatan Asian Games, tetapi potret yang ditampilkan menggunakan sebuah model yang sedang memegang alat panah mampu menggambarkan seorang atlet dari salah satu cabang olahraga yang berbeda dan juga mengenakan baju yang terinspirasi dari budaya asia dengan memperkenalkan latar tempat wisata di Indonesia. Potret pada poster dengan latar Candi Borobudur dengan seorang model yang terlihat sedang memanah, diharapkan mampu membangun semangat olahraga kedalam budaya Asia sehingga diharapkan pula dapat semakin memperkenalkan Indonesia kepada masyarakat Asia dan menarik wisatawan untuk berkunjung sembari menyaksikan perlehatan pertandingan Asian Games 2018.

\section{DAFTAR PUSTAKA}

Ackerman, A., \& Puglisi, B. (2012). The Emotion Thesaurus: A Writer's Guide To Character Expression. CreateSpace Independent Publishing Platform.

Barthes, R. (2011). Mitologi. (Nurhadi, \& A. S. Millah, Penerj.) Bantul: Kreasi Wacana.

Chandler, Daniel. (2002). Semiotics: The Basic. New York, USA: Routhledge

Creswell, J. W. (2010). Research design: pendekatan kualitatif, kuantitatif, dan mixed. Yogjakarta: PT Pustaka Pelajar.

Fitria, M. (2018). Komunikasi Pemasaran melalui Desain Visual. Yogyakarta: Deepublish.

Floyd, K. (2009). Interpersonal Communication The Whole Story .New York: McGraw-Hill

Irawan, Prasetya. 2006. Penelitian Kualitatif \& Kuantitatif Untuk Ilmu-Ilmu Sosial. Departemen Ilmu Adminstrasi FISIP UI. Depok, Indonesia.

Kustandi., Sujipto. (2011). Media Pembelajaran; Manual dan Digital. Bogor: Ghalia Indonesia

Kusumarini, Y. (2006). Teori Semiotic: Universitas Kristen Petra. Surabaya, Indonesia.

Moleong, Lexy J. (2010). Metodologi Penelitian Kualitatif. Bandung, Indonesia: PT Remaja Rosdakarya.

Neuman, W. L. (2017). Metodologi Penelitian Sosial: Pendekatan Kualitatif dan Kuantitatif. (E. T. Sofia, Penerj.) Jakarta Barat: PT Indeks

Pateda, M. (2001). Semantik Leksikal. Jakarta: Rineka Cipta 
Sobur, A. (2016). Semiotika Komunikasi. Bandung: PT Remaja Rosdakarya

Stone, A. M. (2008). Color Design Workbook. Massachusetts, USA.

Suryadi, E. (2018). Strategi Komunikasi. Bandung: PT Remaja Rosdakarya.

Wibowo,W. (2011). Semiotika Komunikasi: Aplikasi Praktis Bagi Penelitian dan Skripsi Komunikasi. Jakarta: Mitra Wacana Media

Wibisono, B. (2018). Satu Menit Baca Bahasa Tubuh Orang Lain. Yogyakarta: Checklist. 